Japanese Research in Business History 2007 | 24

\title{
The Rise and Growth of Small and Medium-sized Enterprises in Industrial Districts ${ }^{1}$
}

- Mechanical Engineering in the Higashi-mikawa District -

\author{
Tomoko HASHINO
}

Kobe University

\section{INTRODUCTION}

7 His PAPER focuses on the influence exerted by two well-known industrial districts in the automobile and motorcycle industry on the development of other industrial districts. More precisely, it focuses on the Higashi-mikawa district, which is sandwiched between the districts of Toyota - the center of automobile production for Toyota - and the Hamamatsu district - the center of motorcycle production for Honda, Suzuki and Yamaha - and analyzes the development of mechanical engineering there, with particular emphasis on the development of small and medium-sized enterprises (SMEs). The Higashi-mikawa district itself can be said to form an industrial district, though it is far smaller in scale than either the Hamamatsu or Toyota districts, and if anything can be said to have developed under their influence. A further characteristic of this district it that it manufactures

1. This paper is a revised and expanded version of Chapter 13 : "Jiritsu-suru chūshō kigyō [The independent SMEs]", the present author's contribution to Yoshitaka Suzuki, Tomoko Hashino and Keishi Shiratori, MBA no tame no Nihon keieishi [Japanese business history for MBA programmes], Tokyo, Yūhikaku, 2007. This research is parcially supported by the Ministry of Education, Culture, Sports, Science and Technology, Grant in Aid for Scientific Research (A) 18203024. 
no final 'end products'.

In the past, SMEs have been regarded as a weak sector of industry, which needs to be protected. They have, however, succeeded in growing and developing in the midst of changing market conditions. The reason that SMEs were able to survive lay in the flexibility which enabled them to participate in a division of labor in areas where they did not need to pursue economies of scale (compared with the large enterprises), and to weather the changes in the economic climate. The main purpose of this paper is to discuss the dynamics of the growth of these SMEs, and their relationship with the industrial districts in which they are located.

In recent years, research on industrial districts has flourished, as scholars from a variety of fields have begun to take an interest in the topic. Hirofumi Ueda has surveyed the trends and changes in scholarly interest in industrial areas (or industrial clusters), and says that it was from the 1980s onwards that industrial districts were seriously taken up as a research topic ${ }^{2}$. Industrial districts are made up of a truly huge number of SMEs. The old 'dual structure' model claimed that within a single economy there existed a high-productivity, high-wage, modern large-enterprise sector, and a low-productivity, low-wage, 'non-modern' small and medium-sized enterprise sector, and took a critical view of the relationship of domination and subordination that was said in many cases to exist between the two. There is also an important research trend, however, which focuses on the industrial districts that are the locus of activity for SMEs as a group, and which, having understood the mechanisms and dynamism of these groupings, attempts to derive policy implications from them ${ }^{3}$. Although it will not be possible in this paper to refer to the policy implications, the present author takes the latter position.

If we look back over history, it was forecasted that the birth of large

2. Hirofumi Ueda, "Sangyō shūseki kenkyū to Higashi Ōsaka no kigyō shūseki [Research on industrial clusters and the industrial cluster of Higashi Osaka]", in Hirofumi Ueda, ed., Sangyō shūseki to chūshō kigyō [Industrial clusters and the small and medium-scale enterprise], Tokyo, Sōfūsha, 2000, pp. 26-27.

3. Shigeru Matsushima, "Atarashii chūshō kigyō ron [A new theory of the small and medium-sized enterprise]", in Hiroyuki Itami, Shigeru Matsushima and Takeo Kikkawa, eds., Sangyō shūseki no honshitsu [The true character of the industrial cluster], Tokyo, Yūhikaku, 1998, pp. 38-39. 
enterprises (large factories) would lead to the disappearance of smalland medium-scale industry. Karl Marx too, observing the rise of the large factory in mid- $19^{\text {th }}$ century Europe, believed this. In fact, however, both in Europe and in Japan, this prophecy proved to have very wide of the mark. If we look at Japan in the first half of the $20^{\text {th }}$ century we see that large factories existed only in the industries 'transplanted' from Western Europe, while 'indigenous Japanese products' such as cotton, silk and woolen cloth, sake, soy sauce, ceramics, lacquerware, Japanese paper, tatami matting, tiles, and the like were manufactured by small and medium-sized firms. Apart from cotton thread and cloth, and raw silk, Japan's main export goods, too, such as knitted cotton goods, ceramics, glassware, toys and canned goods, were the products of smalland medium-scale industry. Nor was that all. Teijirō Ueda has pointed out that even in industries manufacturing the same types of product, 'exceedingly large' and 'exceedingly small' enterprises existed side by side and competed with each other or coexisted, and sought the reason for this in the fact that 'scope existed for competition in areas other than technology and management'. He claimed that a major reason for the ability of relatively small firms to develop without necessarily going in for expansion in scale was due in great part to the existence of external economies resulting from the 'localization of industries' 4 .

As mentioned above, this paper will consider the rise and development of small and medium-sized enterprises with reference to their relationship with industrial districts. It will mainly concentrate on the development of the mechanical engineering industry in the Higashimikawa district of Aichi Prefecture, and the emergence and growth there of SMEs engaged in the manufacture of gear wheels. First, it will look in historical terms at their emergence and development using two case studies, one of an SME which chose to become large-scale, and the other of a firm which took the other option, of not expanding. As mentioned earlier, Higashi-mikawa lies between the motorcycle manufacturing district of Hamamatsu, and the automobile manufacturing district of Toyota, and is a district with unique characteristics, having been influenced by the development of the

4. Teijirō Ueda, Shōkō keiei [Management in commerce and industry], Tokyo, Uedakai, 1984, chapter 4 (Facsimile edition of work first published by Chikuma Shobō, 1930). 
mechanical engineering industry in these two districts. I should like to look in concrete detail, therefore, at what sort of influence the development of these two industrial districts had on the growth of the two selected firms. Further, what was the relationship with the mechanical engineering industry of the district that made it possible for these two firms to achieve their strategic growth objectives? On the other hand, however, it is not always the case that an industrial district bestows benefits on the firms located within it. I shall finally introduce another interesting case where changes in the mechanical engineering industry in the industrial district affected the corporate strategy of the enterprise.

\section{THE INDUSTRIAL DISTRICT AND THE DEVELOPMENT OF SMES}

1. The econornic history of the Higashi-mikawa district since the preWorld War II period

Before discussing the case studies, let us outline the process of development and the main characteristics of the mechanical engineering industry in the Higashi-mikawa district ${ }^{5}$. The term 'Higashi-mikawa' is generally used to refer to the four cities of Toyokawa, Toyohashi, Gamagori, and Shinshiro, and the two counties of Hoi and Atsumi. The district enjoys a favorable location, and is rich in natural resources, and is said to have formed an integrated industrial, economic and cultural unit from ancient times. As is well known, Shizuoka Prefecture, which borders Higashi-mikawa on the east, and the town of Hamamatsu in particular, developed remarkably after World War II, thanks mainly to the motorcycle industry, represented by such firms as Suzuki and Honda, and Yamaha. On the west lies the industrial district that developed around Toyota and its production system. The Higashi-

5. Except where otherwise indicated, the discussion in this section is based on Tomoko Hashino, "Higashi-mikawa ni okeru kikaikōgyō no shūseki to kigyō seichō hagurumakōgyō wo chūshin toshite [The concentration of industry and the growth of enterprises in the Higashi-mikawa mechanical engineering industry - with particular reference to gear-wheel manufacture], in Chūshō kigyō chō [Small and Medium Enterprise Agency], Sangyō no kokusaiteki tenkai to sangyō shūseki ni kansuru chōsa kenkyū hōkokusho [Research report on the internationalization of industry and industrial clusters], 2003. 
mikawa district can be said to lie sandwiched between the industrial districts formed by the two industries - automobiles and motorcycles that have been the pacemakers for postwar Japan's manufacturing industry.

Figure 1 The Higashi-mikawa District and Important Cities in This Chapter

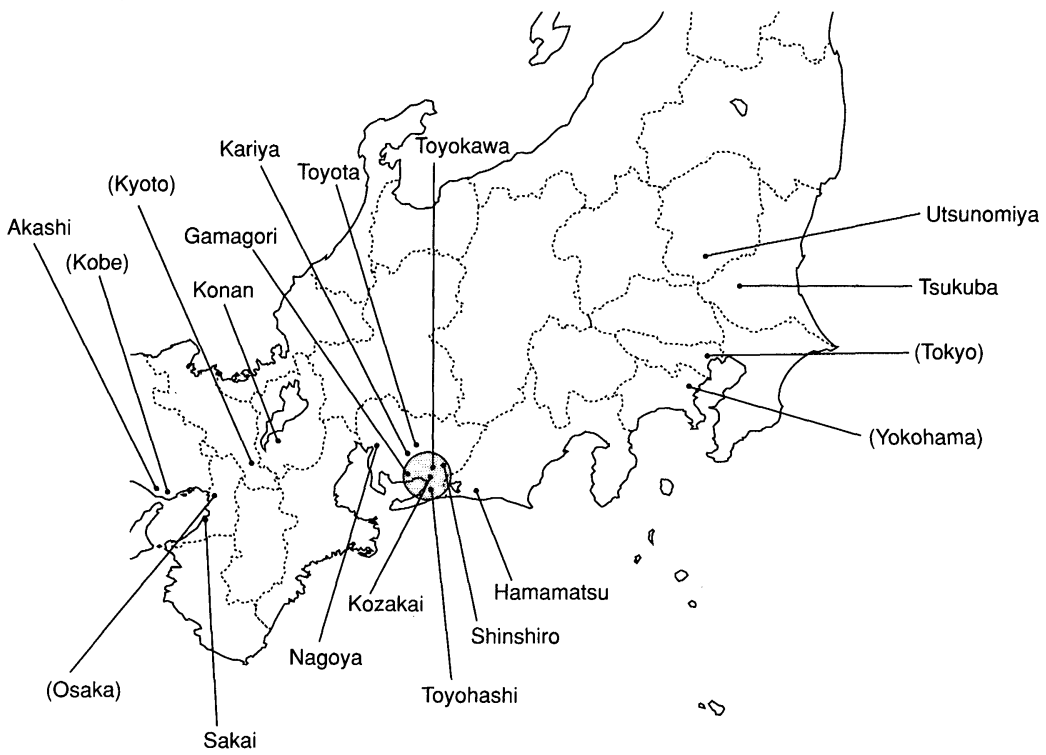

Source: Suzuki et al. 2007, p.275, figure 13-1.

If we refer to Table 1, which shows (for establishments with at least 4 workers) the changes in the number of manufacturing establishments and number of workers in the Higashi-mikawa district, we see that in 1980 there were 1,622 firms, with 38,237 workers, engaged in the iron and steel, non-ferrous metals, metal products, machinery, electrical equipment, transport equipment and precision equipment business. In 1995 , the number of establishments had fallen to 1,264 , but the number of workers, on the other hand, had increased to 50,385. Textiles and craft products, which had accounted for a major share of the total in the earlier period, declined steadily, and we can see clearly that there a shift to heavy and chemical industry had taken place. 
Table 1 Changes in the Number of Manufacturing Establishments and Number of Workers in the Higashi-mikawa District

\begin{tabular}{|c|c|c|c|c|c|c|c|c|}
\hline & \multicolumn{4}{|c|}{ Number of establishments } & \multicolumn{4}{|c|}{ Number of workers } \\
\hline & 1980 & 1985 & 1990 & 1995 & 1980 & 1985 & 1990 & 1995 \\
\hline Food & 706 & 408 & 383 & 346 & 10451 & 9037 & 9279 & 8483 \\
\hline $\begin{array}{l}\text { Beverages and animal } \\
\text { feed }\end{array}$ & & 50 & 38 & 37 & & 810 & 712 & 711 \\
\hline Textiles and craft products & 1511 & 732 & 602 & 425 & 14373 & 10908 & 8993 & 5594 \\
\hline Clothing and accessories & 318 & 226 & 235 & 284 & 2076 & 2275 & 2293 & 2996 \\
\hline Timber and timber products & 420 & 231 & 211 & 191 & 4478 & 2762 & 2873 & 2564 \\
\hline Furniture and fixtures & 392 & 171 & 157 & 129 & 3452 & 2610 & 2586 & 1933 \\
\hline Paper and paper products & 91 & 63 & 66 & 74 & 992 & 873 & 2630 & 1339 \\
\hline Printing and publishing & 217 & 115 & 112 & 106 & 1620 & 1378 & 1383 & 1312 \\
\hline Chemical engineering & 27 & 24 & 25 & 22 & 1914 & 2120 & 2187 & 2220 \\
\hline $\begin{array}{l}\text { Petroleum and Coal } \\
\text { Products }\end{array}$ & 6 & 7 & 5 & 4 & 26 & 69 & 38 & 42 \\
\hline Plastics products & 141 & 178 & 198 & & 3943 & 3881 & 6342 & \\
\hline Rubber products & 30 & 21 & 19 & 19 & 1164 & 1046 & 1195 & 1154 \\
\hline Leather and leather goods & 34 & 17 & 11 & 11 & 271 & 203 & 109 & 91 \\
\hline $\begin{array}{l}\text { Ceramics, clay and stone } \\
\text { products }\end{array}$ & 110 & 73 & 79 & 76 & 1997 & 1731 & 1616 & 1473 \\
\hline Iron and steel & 57 & 57 & 50 & 48 & 3102 & 3049 & 2833 & 2621 \\
\hline Non-ferrous metals & 36 & 30 & 25 & 21 & 1255 & 1186 & 1318 & 1243 \\
\hline Metal products & 423 & 243 & 269 & 274 & 4708 & 4770 & 4940 & 4524 \\
\hline Machinery & 529 & 367 & 429 & 377 & 8822 & 9758 & 10433 & 9508 \\
\hline Electrical equipment & 139 & 165 & 181 & 185 & 5091 & 6974 & 6883 & 7614 \\
\hline Transport equipment & 363 & 271 & 283 & 309 & 11565 & 15833 & 21721 & 22391 \\
\hline Precision equipment & 75 & 73 & 81 & 50 & 3694 & 4249 & 4406 & 2484 \\
\hline Other & 355 & 76 & 70 & 87 & 3835 & 841 & 985 & 1291 \\
\hline Total & 5838 & 3561 & 3509 & 3273 & 84886 & 86425 & 93294 & 87950 \\
\hline
\end{tabular}

Source: Hashino, op.cit. Figures are for establishments with four or more workers.

This district was one where light industry had been predominant, specializing in the production of textiles, timber products, and food, centered on Toyohashi and Gamagori. If we except the light industry that had developed in the modern period, the region had no specialized local products. Before World War II, in fact, mechanical engineering in Higashi-mikawa has been insignificant. It is said, however, that with the 
establishment of a naval arsenal in Toyokawa in 1939 there was a growth of related industry in the vicinity of the new plant.

Let us now trace, in broad terms, the development of mechanical engineering in Toyohashi, Gamagori and Toyokawa, the three cities which are now the center of the industry. By doing so we shall be able to delineate the historical background of the small and medium-sized enterprises that developed there ${ }^{6}$.

In Toyohashi prior to the period of modern economic growth, the manufacture of sickles for agricultural use flourished. The development of the manufacture of agricultural tools of this sort was largely thanks to the existence of a wide expanse of agricultural land in the Mikawa Plain. After the end of the $19^{\text {th }}$ century, silk production developed, and after World War II as the overseas and domestic demand for raw silk fell dramatically with the growth of the synthetic textile industry, textiles, food, timber and timber products, and mechanical engineering became the four main industries of Toyohashi. As military-related production grew after the Manchurian Incident, the development of mechanical engineering and metalworking accelerated, leaving behind the earlier textile machinery, woodworking machinery, agricultural implement and sheet-metal working industries. In 1933 there were only 5 factories with 5 or more employees in the engineering and metalworking sector. These increased to 18 factories in 1934, 36 in 1936, and 52 in 1937.

The manufacturing activities of the firms which led the mechanical engineering and metalworking industry in Toyohashi at this time were stimulated by the presence of the Toyokawa Naval Arsenal, and the _saki Naval Airfield. These firms, together with a large number of subcontractors, were mainly responsible for the production of aircraft parts, machine guns, and ammunition. However, the majority of factories were destroyed in the bombing immediately prior to the end of World War II, and once the war ended the naval arsenal was closed.

6. The information below concerning Toyohashi is from Yūji Ichijō et.al., Toyohashi no kikai kinzoku kōgyō no gaiyō [An outline of the mechanical engineering industry in Toyohashi], Aichi daigaku chōbu chihō sangyō kenkyūsho kenkyū hōkokusho, 10, 1963; concerning Gamagori from Yūji Ichijō, Gamagōri no tekkōgyō [The Gamagori ironworking industry], Aichi daigaku chūbu chihō sangyō kenkyūsho kenkyū hōkokusho, 13, 1965; and concerning Toyokawa from Shinpen Toyokawa-shishi henshū iinkai [Editorial committee for the new edition of the history of Toyokawa City], ed., Shinpen Toyokawa-shishi dai-8 kan [History of Toyokawa City, new edition, vol. 8], 2002. 
Immediately after the end of the war there was some production of cutlery such as forks and spoons, of agricultural implements, and of household goods such as can openers, dry battery cases, and safety razors, but as the postwar recovery proceeded, the production of parts in their specialized field was placed on a firmer footing, and expanded into looms, agricultural implements (not only hoes and sickles, but also spraying equipment, hulling and threshing machines etc.), metal products (bearings, vehicles, valves, etc.), sewing machines, cameras, and food processing equipment. The parts production technology that had been developed during the war was preserved in the postwar period, making possible the birth of a large number of mechanical engineering and metalworking factories, minute in scale though they were. These firms gradually forged links with manufacturers in Hamamatsu, Toyota, Kariya, and Nagoya, and thus succeeded in expanding into the manufacture of parts for the automobile and motorcycle industries.

Gamagori, to which we next turn our attention, used to be known for 'weaving, fishing and tourism'. This area was known for the production of 'Mikawa cotton', and even after World War II, was home to a flourishing textile industry. There was some related ironfounding work, casting loom parts, but a notable feature of this town was the very small number of firms in the engineering and metalworking sector that had been founded before World War II. According to Ichijō's outstanding survey research on the members of the Gamagori Association of Ironworkers, of the 52 firms (out of 68) which responded to his questionnaire, only 9 had been established in the prewar period ${ }^{7}$. These firms had gone over to military production during the war, but after the war reverted to the manufacture of their prewar product lines, and served as pioneers of the metalworking industry in Gamagori. The Gamagori Brach of the Kowa Company Ltd. had been engaged in military production, but after the war started to manufacture precision optical equipment such as lenses, cameras and binoculars, and the Gamagori metalworking industry developed as subcontractors supplying parts to Kowa. Later, as the demand for durable consumer goods rose, factories were established to manufacture parts for automobiles, sewing

7. Yūji Ichijō, Gamagōri no tekkōgyō [The Gamagori ironworking industry], Aichi daigaku chūbu chihō sangyō kenkyūsho kenkyū hōkokusho, 13. 
machines and the like, and many of the firms which had originally been manufacturing optical equipment parts also gradually switched over. We can assume that it was during this process that relations with automobile companies in Nagoya and Kariya - in the same Prefecture - gradually strengthened. We can see a progression from sewing machine, washing machine and knitting machine parts as well as motorcycle parts in the 1950s, through to automobile parts (including light four-wheel vehicles), mainly for Toyota, Honda, Suzuki and Yamaha, in the 1960s and 1970s. They also manufactured their own products, such as ropemaking equipment, blowlamps, shovels, vices and so on. From 1973 onwards their main product had become automobile parts, which remains the case to this day.

Finally let us turn our attention to Toyokawa. Until the construction in 1939 of the Toyokawa Naval Arsenal, some 165 hectares in area and said to be the largest in the Orient, a wide area of open land known as Honnogahara occupied what is now the center of Toyokawa City. At first the main product manufactured at the Toyokawa Naval Arsenal was machine guns, but an optical department, a fire control systems department and an equipment department were later added, creating a large-scale munitions facility. By 1942 the town's population had grown to 70,000 , said to be 25 times its prewar level. As related facilities were constructed, there soon arose a need for the functions appropriate to what had now become an urban factory town. Consequently, as the Naval Arsenal expanded, the local villages and towns merged, and in 1943 the City of Toyokawa was born. On August 7th, 1945, days before the war was to end, the city suffered a massive bombing raid by the U.S. Air Force.

Although the arsenal had been destroyed by the air raid, there were buildings remaining around it that were used as a teachers' training college, the city hall, public housing, and schools. The area that had originally been a center of agricultural production and the production of chests of drawers and other furniture had escaped war damage, the finances of Toyokawa City, now that it had lost the naval arsenal, were in a perilous state. From the mid-1950s, the Toyokawa Association of Ironworkers, which had been born out of the Toyokawa Association of Commerce and Industry successfully campaigned for the equipment of the Toyokawa Naval Arsenal to be sold off, and the machinery was sold 
to firms in the Higashi-mikawa district. Firms were invited to set up on the former site of the naval arsenal, and in a very short time the site became home to a major industrial estate. The optical business that had been part of the arsenal's activities was taken over by Chiyoda Kogaku which continued to operate and develop in the district. It later changed its name to Minolta, and is now part of the Konica Minolta group.

In this way, the formation of an industrial district in Higashi-mikawa, and its subsequent shift into the heavy and chemical engineering sector owes much to the influence in the prewar period of the Toyokawa Naval Arsenal, and in the postwar period of the development of the sewing machine, motorcycle and automobile industries in the surrounding region. Let us now consider the historical development of two typical firms which, against the above background, developed respectively from a small smithy, and a backstreet workshop, to grow into small/medium enterprises.

\section{Responding to large-scale mass production enterprises - the growth} and development of Musashi Seimitsu Industry Co., Ltd.

Musashi Seimitsu, with its head office in Toyohashi, is engaged in the manufacture and sale of transport equipment ${ }^{8}$. The group as a whole has some 8,000 employees, with 7 domestic and 11 overseas production plants (as of March 2006). At the end of the financial year 2001 its Head Office factory in Ueta, Toyohashi had 900 full-time employees and is listed on the First Section of the Tokyo and Nagoya Stock Exchanges. In the accounting period to March 2005 it was capitalized at $¥ 2,973.6$ million and registered sales of $¥ 62,616$ million; its consolidated sales amounted to $¥ 107,246$ million. Its main customers at the present time are Honda Motor, Ltd., Audi, Siam Toyota Manufacturing Co. Ltd, GM, Suzuki, Daihatsu, MDC Power, Hyundai, Fiat, Ford, Fuji Heavy

8. The profile and history of Musashi Seimitsu outlined here is drawn from the following sources: the company's website; Tomoko Hashino, "Musashi Seimitsu Kabushiki Kaisha [Musashi Seimitsu Co., Ltd.]" and "Musashi Seimitsu - Nagata Tekkō [Musashi Seimitsu and Nagata Tekko] in Hosei daigaku sangyō jōhō sentā, Heisei 13nendo sangyō shūseki to sangyō hatten no dainamizumu ni kansuru chōsa kenkyū [2001 survey research on the dynamism of industrial clusters and industrial development], Chūshō kigyō chō [Small and Medium Enterprise Agency], 2002; Yoshiharu Ōtsuka, Watakushi no omoide [My reminiscences], not commercially published, 1995. 
Industries Ltd., Mitsubishi Motors, Kawasaki Heavy Industries, Ltd., Kubota Corporation, Aishin Seiki Co., Ltd., Visteon, F.C.C., Koyo Seiko ${ }^{9}$, Showa, DANA, Denso, Benteler and Mitsubishi Heavy Industries, Ltd.

Let us look at the history of this corporation, to see how it developed from the small smithy that it once was to its present status. When we do so, we can see that there were a number of important turning points: the first period lasts from the firm's foundation to Japan's defeat in World War II. The second turning point is its entry into the sewing machine industry after the war; followed by the selling off of the equipment of the Toyokawa Naval Arsenal. These were succeeded by the start of dealings with Honda, the firm's subsequent introduction of cold forging technology, and the establishment of Kyushu Musashi Seimitsu.

The period from the firm's foundation to defeat in the war was the era dominated by its founder, Yoshiharu Ötsuka. Ötsuka was born in 1905 in what is now Toyohashi City. In 1919, at the height of the World War I economic boom, he left higher elementary school in his second year, without graduating, and became an apprentice at the Osaki Machine Works in Gotanda, Tokyo. When that firm closed down in 1926 he moved to the Kato Machine Works in Shinagawa, Tokyo (a designated supplier for the National Railways), and in 1929 to the Nakajima Aircraft Corporation. In 1938 he set up the Otsuka Seisakusho in Shinagawa with 5 employees, and equipment consisting of 3 milling machines, 5 lathes, 2 drilling machines and other necessary tools. The firm's first order, received from Ishiwata Machine Works (a successor to the former Osaki Machine Works), was for aircraft propeller retainers.

In 1939 the firm moved to Sekimae in Musashino City, within 1.5 kilometers of the Musashino Plant of the Nakajima Aircraft Company. This is the origin of the firm's present title, Musashi Seiki. The first order the firm received here was from Nakajima, for aircraft engine carburetor air control shafts. Other firms had also been given orders for these pats, but such was the quality of Musashi Seiki's product that thereafter they were awarded all the orders. Their record was so good that they started to receive orders for parts vital to the aircraft engine's

9. This was its name at the time of the survey. On April 1, 2007 it merged with Toyota Koki Co., Ltd., and became JTEKT. 
performance, and in 1942 the factory was designated an 'important aircraft engine parts supplier', and placed under military control. In the following year the firm was transformed into a joint stock company, and was renamed Ōtsuka Aircraft Co. Ltd.. To avoid the danger of air raids the firm was relocated to Shinjō in Yamagata Prefecture (nothern part of Japan) and remained there until Japan's defeat.

After the end of the war the founder purchased some governmentowned laud near his home town of Toyohashi, and farmed it for a time, but in 1948 he established a factory once again (naming it Musashi Industries Ltd.), to manufacture sewing machine balance cams. It is said that the quality of the balance cam affects the sound of the sewing machine when it is in operation; if the materials and manufacture are unsatisfactory, the sewing machine will get a bad reputation for being noisy. After considerable effort he managed to develop a balance cam that made sewing 'silent and smooth', which he was able to sell to manufacturers in Osaka, where he set up a branch office (opened in 1958, closed down in 1964). At one time the firm's products had a market share of between $50 \%$ and $60 \%$ of the Japanese market. Kimitoshi Ōtsuka (the founder's son; as of 2003 senior advisor to the firm) joined the firm in 1957. His first job was the marketing of sewing machine parts. At that time, he recalls, the firm had about 40 employees. However, the establishment of JIS standards for sewing machines prompted a large number of makers to enter the market. Oversupply dragged down prices, and the market was taken over by Asian manufacturers with their lower labor costs. In the end the firm sold both its cam manufacturing equipment and its goodwill to an Osaka company and withdrew from the manufacture of sewing machine parts. In 1955 they had the opportunity to purchase some of the equipment from the former Toyokawa Naval Arsenal; they bought a jig borer at this time.

While collecting information in order to find work to replace sewing machine parts manufacture they became aware that the Honda Motor Co. was selling motorcycles that were very popular with the younger generation. Yoshiharu Ötsuka, the firm's founder, decided to visit Honda. When he did so, he met an old acquaintance, Hiroshi Takeshima, whom he had known when he, Ōtsuka, was working as a foreman in the machine shop at Nakajima Aircraft. Takeshima at that time was a design engineer seconded to Nakajima Aircraft from the Ministry of Commerce 
and Industry (now METI). This reunion was to prove a major turning point for Musashi Seimitsu. Takeshima was now Manager of the Honda Hamamatsu plant, and through him Ōtsuka was able to meet Sōichirō Honda, the company's President.

Ōtsuka obtained interest-free finance of $¥ 10$ million from Sōichirō Honda, which enabled him to modernize his machinery and equipment. As production of Honda's Super Cub motorcycle increased, the firm changed its name to Musashi Seimitsu, and committed itself completely to the production of such parts as camshafts, drive gears, and shifting gears for the motorcycle industry. Using and additional $¥ 30$ of financing from Honda Motor, the firm was able further to modernize its equipment, purchasing a Miyano automatic lathe and a Hitachi turret.

However, instead of outsourcing drive gears to Musashi Seimitsu, Honda's Suzuka plant decided to cut the parts themselves, using a German Schütte six-spindle automatic, since they could thereby cut their costs by $¥ 5$ per gear. In response, Musashi reduced their cost by reducing the amount of cold forging and milling required, by preforging the parts (roughly forging the parts in a press beforehand to drastically reduce the amount of cutting required), a process rarely used at the time. In the course of introducing this procedure, Musashi Seimitsu realized the benefits to be obtained by not only undertaking the processing, but by integrating the manufacturing procedure from the raw material stage through to the finished product, and were able to put forging technology on a firm basis within their own plant. Later, when Honda went into the production of four-wheeled vehicles, Musashi were able to undertake the manufacture of parts for these, concentrating particularly on suspension system parts.

In 1976 the company established Kyushu Musashi Seimitsu in Kumamoto, on the island of Kyushu. This was a result of an invitation from Honda, who were concentrating their motorcycle production in Kumamoto, and setting up a base of operations there to oversee and supply both their domestic and overseas operations. This resulted in a division of labor, with motorcycles being manufactured in Kyushu, and four-wheeled vehicles in Toyohashi. Kyushu Musashi pushed forward with their integrated production of parts, from raw materials through to the finished product. Further, in 1978, they began to do business with Ford of America, selling ball joints, their main product. This prompted 
them to expand into the United States, establishing a plant in Battle Creek, Michigan. In 1987, again at the invitation of Honda, they set up a plant in Thailand and started production of parts for Honda motorcycles there. This was followed by expansion into the U.K. (1993), Indonesia and Brazil (1996), and Canada (1997).

\section{High-mix low-volume production - the Case of Nagata Tekko}

Nagata Tekko Co., Ltd. (hereafter referred to as Nagata Tekko) is a specialized gear wheel manufacturer located in the town of Kozakai in Hoi County ${ }^{10}$. Its main business is the manufacture and sale of precision gear wheels, the manufacture and sale of specialized machine tools, and the heat treatment of metals. When the firm was founded its factory was located in the city of Toyohashi, but in 1961 expansion of its plant prompted the move to its present location. 1946 is reported as the date of its foundation, but it had as a predecessor a metalworking business founded before World War II by the present firm's founder (the father of the firm's current President) who was born in 1907. At present Nagata Tekko is capitalized at $¥ 72.5$ million, has 150 employees (of whom 20 are women), and an annual turnover of $¥ 3.5$ billion. Its main customers are Kubota Corporation, Kawasaki Heavy Industries Ltd., Hitachi Ltd., Ebara Corporation, Sumitomo Heavy Industries, Ltd., Harmonic Drive Systems Inc, and Nidec Corporation, which together account for some $50 \%$ of the firm's annual sales. They say, however that they try to let no single firm account for over $25 \%$ of their business. They deal annually with about 150 separate customers, extending from Akita Prefecture in the north of the country to Kagoshima in the south.

The founder's family were blacksmiths by trade, and it is said that he learned his trade there before striking out on his own. When the founder was drafted into the armed forces he found his employees jobs with other factories, sold off his equipment, and closed his factory. In the army he served as a machinist, and on demobilization in 1945, restarted

10. For the history of Nagata Tekko, see the company's website, and Tomoko Hashino, "Nagata tekkō: Kosaka Eiichi, Ikuko fusai e no hiaringu [Interview with Mr. Eiichi Kosaka and Mrs. Ikuko Kosaka of Nagata Tekko]", and "Nagata tekkō kabushiki kaisha hōmon kiroku [Record of a visit to Nagata Tekko Co., Ltd.] in Hosei daigaku sangyō jōhō sentā, op.cit.. 
his business. His wartime experience as a machinist was to stand him in good stead when it came to purchases of machinery for the establishment and expansion of his plant.

Immediately after World War II he turned his hand to a variety of work. The first of these was textile machinery, for which he designed a cotton knitting machine. By 1955, when he was able to purchase machinery sold off from the former Toyokawa Naval Arsenal, he was making parts for motorcycles and agricultural machinery. It is from this time that he embarked on the mass production of gear wheels. At the time his main customers were Suzuki and Yamaha, but he then received an order from Honda. It is said that when an order from Honda came in, the atmosphere in the factory became very tense. This was because while at that time Yamaha were inspecting every item that suppliers delivered, Honda carried out only spot checks. During the Korean War the firm also manufactured gears needed for the repair of Jeeps, and also produced bevel gears ordered by Denso. When the equipment of the Toyokawa Naval Arsenal was sold off, they were able to purchase a general purpose machine which was the most sophisticated of its type at the time, and made it possible for the firm to manufacture a wide variety of parts. Around this time the firm had about 50 employees.

They say that if they received an order for motorcycle parts - cranks, shafts or gears - they would manufacture them, whatever they were. In 1955 they established a system for the mass production of gears, and in 1957 became a specialized gear manufacturer. At the time they were receiving orders for motorcycle parts from Suzuki, Honda and Kawasaki, and at first were manufacturing cranks, shafts and gears. They decided to specialize in gear manufacture and to refuse orders for other parts. By doing so they were able to concentrate their new investments on gear manufacturing equipment.

At the time they made this decision to specialize, they were apparently greatly influenced by the enactment of the Provisional Law to Promote the Machinery Industry ${ }^{11}$. In order to receive designation

11. Concerning the effects of this law, see Konosuke Odaka, "Evaluating Japanese Industrial Policy: The Auto-Parts Industry Example", in Odaka and Sawai, eds., Small Firms, Large Concerns: The Development of Small Business in Comparative Perspective (Fuji Business History Series), Oxford University Press, 2003, which refers to the case of automobile parts suppliers. 
under this law, a firm had to submit practical plans for investment in equipment and the modernization of management. If these were approved by the Ministry of International Trade and Industry (MITI, now METI), the firm would be eligible to receive funding from financial institutions (the Japan Development Bank or the Japan Finance Corporation for Small Business). The founder's son-in-law, Eiichi Kosaka, who had been working for Takashimaya, an old-established department store, since graduating from Keio University, joined the firm with responsibility for accounts and management, and was involved in drawing up these plans. By receiving designation under this law, Nagata Tekko says that they were able (1) to obtain the funds required to concentrate their investments on gear production, (2) to establish a favorable position vis-à-vis commercial financial institutions, (3) to lay out long-term management policy for the firm by drawing up practical plans, and (4) to accumulate internal reserves, thanks to the special depreciation system permitted under the law. Thanks to these internal reserves, they were able to purchase high quality inspection equipment, the data obtained from which was to be indispensable for raising confidence in the quality of their product.

By 1961 the firm had completed its conversion into a specialized gear wheel manufacturer, and started actively purchasing under a 5-year plan. They later established a heat treatment plant (1966) and a gear grinding division (1968). In 1973 they actively expanded the gear grinding division and began thread and rack grinding. While pushing ahead with the repair and modernization of their manufacturing and heat treatment plants, they completed the development of equipment for grinding very small gears (1996), constructed a dedicated machinery maintenance plant (1998), and set up a separate division for the grinding of small gear wheels (2001).

There are three levels of precision for gears: ranks A, B, and C. A is the highest level of precision, and applies to gears for printers, and reduction gears for industrial robots, B to gears for automobiles and motorcycles, and $\mathrm{C}$ to gears used in agricultural machinery. Sizes can vary from gears used in shipbuilding, to minute gears. Nagata Tekko has specialized in gear manufacture, claiming that they 'will fill orders for 10 gears, or for 10 thousand,' and simultaneously manufacturing gears of different levels of precision has assisted in the efficient utilization of 
their machinery and facilities. At present, with the future in mind, the firm is building a survival strategy of manufacturing products that noone else can make, creating a structure for the high-mix low-volume production of high-quality precision gears. By producing 'branded gears' they believe they can survive as an independent gear manufacturer, rather than just a parts supplier or subcontractor.

III THE CONDITIONS FOR THE DEVELOPMENT OF SMES :

WITH PARTICULAR ATTENTION TO THEIR RELATIONSHIP WITH

LARGE FIRMS AND WITH INDUSTRIAL DISTRICTS

\section{Dealing with large firms}

Above we have looked at two contrasting cases. They have in common the fact that both are specialized gear manufacturers located in the Higashi-mikawa district, both can trace their history back to before the Second World War, and both their founders started out as small-scale blacksmiths. Their founders were highly conversant with the practical skills of metal processing had had overcome a number of vicissitudes. In this sense they perhaps had furnished themselves with the factors required for their future development.

In the period of expanding production after World War II, one deepened its relationship with Honda - though without becoming tied exclusively to Honda - and turned itself into a specialized manufacturer of motorcycle and automobile parts. Aiming at the integrated production of gears, it established a mass production system by introducing forging technology, and increased the scale of the enterprise. By replacing part of the grinding process by forging - a procedure unusual at the time they were able to compete in terms of cost with parts produced in-house by the large manufacturer. Further, as Honda expanded geographically, both within and outside Japan, the firm set up new factories near to those of Honda, further consolidating its position as a parts supplier. On the other hand, as the firm grew, it made parts for motorcycles and automobiles at the same time as it moved towards becoming a specialized gear manufacturer, but refrained from increasing the scale of the enterprise, avoiding excessive dependence on the custom of a specific industry or company. We can say that, if anything, the firm 
made orders from Honda work to its advantage, in that they raised the level of tension within the factory and implanted an awareness of the importance of quality control. We can see here a deliberate strategy though which by making small-lot production rather than mass production its forte, the firm avoided turning into a mere subcontractor.

We can discern here a relationship between the pattern of dealings with large companies and the direction of development of the small and medium-sized enterprise. Musashi Seimitsu can be said to have defined the route that its expansion would take by becoming a powerful cooperating supplier for Honda. This route was that of mass production and increasing scale. Committing themselves to the motorcycle and automobile industry, with its rapid growth and its furious pace of model changes, implied that Musashi Seimitsu would choose the option of enlarging its scale with a system of mass production enabling it to supply parts at low cost. The Japanese car market, however, is characterized by diversity and a wide range of models. The firm therefore cut its costs by being one of the first to adopt the method of first forming the gear teeth by forging - an unusual process at the time and then machining the parts where precision was demanded. At the same time it chose not to create a production line for the chain of processes from forging through machining, heat treatment (carburizing and quenching), grinding, assembly, through to inspection and dispatch. By having each process complete in itself, as it were, the firm was able to avoid the inefficiencies that arise when an increase in the variety of lots on a production line makes tooling changes necessary. Further, great emphasis was placed on increasing the efficiency of the forging process, and a great deal of experience and know-how was accumulated. This is a process where heated steel is forged, and the firm has aimed to speed up this process through the combination of human skills and machinery. It is reported that the bevel gears manufactured in the firm's main factory by the pre-forging process are delivered in approximately equal quantities to Honda and to Ford ${ }^{12}$.

The creation of this sort of dealing relationship with a major

12. Concerning the reasons why automobile assemblers such as Toyota and Nissan have encouraged their parts suppliers to deal with other assemblers, rather than only with themselves, see Suzuki, Hashino and Shiratori, op.cit., chapter 11. 
enterprise can guarantee to an SME a demand for its products. But at the same time it also means that the firm must firmly link itself to the corporate growth and market expansion of its trading partner. By contrast, Nagata Tekko consolidated its parts manufacturing system as the motorcycle and automobile industries expanded, but avoided becoming dependent on a single corporate customer, even as it furnished itself with the ability to become a specialized gear manufacturer. By avoiding an excessive commitment to the automobile industry, it made sure that its independent decision-making concerning corporate strategy was not restricted. When Yamaha threatened to cut off orders to the firm unless it became an exclusive Yamaha supplier, it apparently bought land in the city of Tenryū, and established a firm called Tenryū Gears (which was later sold off). While accepting orders from a range of companies such as Suzuki, Honda and Marusho, it was able to 'use' the Honda connection to raise the awareness of quality control within the plant. They also claim that they were aware that Musashi Seimitsu, located in the same area, was strengthening its relationship with Honda, and made a conscious decision not to compete.

\section{Corporate growth within an industrial district}

The reason that Nagata Tekko, even while moving towards becoming a specialized gear manufacturer, avoided excessive dependence on a particular industry or firm was in order to spread the risk of a sudden decrease in demand. The strategy that Nagata Tekko adopted to respond to the diverse orders from its customers was to use the network of firms with the industrial district. During the period of rapid economic growth it was possible for an employee to set up an independent firm with just one or two lathes. Many of the employees of Nagata Tekko were the younger sons of farming families who had come out to the city to work, instead of remaining on the farm. They would then, it is said, build flimsy barrack-like workshops and go into business for themselves. A Nagata representative would go round these small workshops delivering raw materials and collecting the finished product.

At present Nagata Tekko outsources: (1) lathe work, (2) heat treatment, (3) transport, (4) gears (finished products), and (5) raw materials. Lathe work is outsourced to about 30 companies, and a 
'Nagata Tekko Suppliers Association' has been established. $85 \%$ of these firms are located within 50 kilometers (1 hour) of the Nagata Tekko plant. Deliveries are normally twice a week, but in emergencies Nagata Tekko will send someone to fetch the goods. The smallest of these suppliers are one-man workshops with a single lathe, with the largest having no more than 20 workers. Nagata Tekko has its own heat treatment facilities, but also outsources to Enshu Kogyo in Hamamatsu, CNK in Nishi-mikawa and Onex Corporation in Atsugi, which is a designated supplier for Sumitomo Heavy Industries. Heat treatment is carried out internally for mass-produced products.

A regular daily transport service is used for deliveries to Kawasaki Heavy Industries in Akashi, and Kubota in Sakai, Utsunomiya and Tsukuba. When the firm outsources gears themselves, they use Delta Kogyo in Nagoya, and Toyokawa Gear, which is run by the cousin of Nagata Tekko's President. Raw materials are purchased from Gohsyu Ltd., a forging firm in Konan, Shiga Prefecture. Gohsyu is a subcontractor for Honda, and started business with Nagata Tekko when the latter started receiving orders from Kubota.

In this way, Nagata Tekko chose a route to expansion within limits where production remained possible within its industrial district, so that they could respond to diverse demand without excessive dependence on a single customer. This is presumably possible because suppliers with enough technical skill to respond to Nagata Tekko's requirements continue to exist in the vicinity. Of course, even Musashi Seimitsu uses outsourcing to some extent, but within strict limits, and restricted only to grinding processes. The outsourcing even of grinding is limited to products whose manufacture cannot be automated, products with a monthly volume of between 500 and 1,000 units, and when there is insufficient production capacity in-house. The firm uses between 20 and 30 specialist grinding subcontractors. Since the reason they are used is to reduce costs, there is no compelling reason for them to be located within the district. This is because the Musashi Seimitsu strategy was to set up parts factories in the places to which Honda had located its plants. In this way, as far as Musashi Seimitsu is concerned, the Higashimikawa industrial district is important in that is near to Hamamatsu, the birthplace of the company, but in terms of the history of the company's development we should place more emphasis on the founder's training 
and first business in Tokyo, on its business relations with Honda, and on the introduction of forging technology.

By contrast, the Higashi-mikawa industrial district has considerable significance in the history of both its birth and its development. On the one hand, its birth owes much to the founder's beginnings as a local blacksmith and to the development locally of the textile industry and the motorcycle and automobile industries. Surely its development too owes a great deal to the network within the district formed by the spin-off of former employees who have gone into business on their own.

\section{BY WAY OF A CONCLUSION : THE BENEFITS AND LIMITS OF} THE INDUSTRIAL DISTRICT

This paper has discussed the growth of two contrasting SMEs that originated in the same industrial district. One of them was a case where the firm increased in scale by linking its own growth to its relationship with a particular industry and a particular firm. The other made skilful use of the local network, diversified its customer base, and grew into a specialized manufacturer by using as a weapon a highly diversified product range. They were sandwiched between two industrial districts, in both of which manufacturing industry was developing rapidly. In order to respond to the demand from these districts the role played by the Higashi-mikawa industrial district was highly significant, in terms of the history of both their birth and their development.

However, it must be pointed out that, even though the industrial district analyzed in this paper provided an important basis supporting the independence of small and medium-sized enterprises, it did not invariably provide benefits. As we saw above, a large number of small and minute enterprises are competing for subcontracting work. If the metabolism as a whole is active, then this will no doubt be important for the development of small and medium-sized enterprises. However, the example that we shall consider below, that of the Nakamura Gear \& Machinery Corporation shows us that this is not always the case.

The Nakamura Gear \& Machinery Corporation (hereafter 'Nakamura Seiki') is a manufacturer of a range of automobile gear parts, based in the Higashi-mikawa industrial district. It was established in 1955 with a capital of $¥ 20$ million, and an annual turnover in 2005 of $¥ 9.2$ billion. Its 
main products are AT gears, speedometer gears, and gears for electronic equipment and industrial machinery. Its main customers include Aisin Aw Co., Ltd., Aishin Seiki Co., Ltd., Aishin AI Co., Ltd., Aishin Kiko Co., Ltd., and Kayaba Manufacturing Co., Ltd.. For products in small lots (jigs and products) it uses some 30 subcontractors. These are small workshops with 2 or 3 employees, some of which are run by former employees of the previous President who went independent with a single lathe. Nowadays, however, the high cost of equipment is said to have made this route to independence extremely difficult.

Originally, the only work that Nakamura Seiki carried out in-house was the grinding of gear teeth, but they are now apparently pushing forward with integrated production, and have recently constructed a factory for this purpose. This is because, as the automatic gearbox becomes the norm in the automobile, and high-precision gears become necessary, this level of precision cannot be obtained by improving the precision of their own processes alone. To produce high-precision products, a specific level of technical expertise is necessary at every stage of the manufacturing process. It is necessary, in other words, for the technical level of the subcontractors within the industrial district, to whom a variety of processes are being outsourced, to be constantly maintained at a specific high level.

In other words, there is no guarantee that the unique externalities possessed by the industrial district, that Alfred Marshall pointed out in the past, will be consistently and permanently present. If the division of labor within the industrial district becomes impossible, in cases like that of Nagata Tekko, described above, a major revision of their strategy is likely to be unavoidable. If we consider the constraints inherent in the historical background of the development of the industrial district we have discussed here - the establishment of mechanical engineering thanks to orders from the naval arsenal, and the postwar development thanks to increasing demand from outside the district - it would have been possible for no close division of labor relations to have developed within the district. The extent to which horizontal relationships have formed and developed within the industrial district is a topic which should be considered in future research.

The existence of industrial districts containing large numbers of small and medium-sized enterprises was an essential factor supporting 
the development of the postwar Japanese production system. If we consider small and medium-sized enterprises in this way, from the viewpoint of their relationship with industrial districts or clusters, the mechanisms and dynamics involved can be understood. It is surely possible to draw out positive policy implications from this fact. 